\title{
Community Religiosity Study of Social Reality in the Perspective of Symbolic Interactionism in the Trowulan Society of Indonesia
}

\author{
Affan Hasnan Mubarok, I Made Weni, and Tommy Hariyanto
}

University of Merdeka Malang, Indonesia

\begin{abstract}
This research is a qualitative research about the religious life (Religiosity) of the Trowulan community. This research is motivated by the turbulent situation in the latest conditions which have an impact on moral decadence and despair in the wider community. The focus of the research is directed to two research questions, namely how is the religiosity of the Trowulan community and what symbols of religiosity can be captured and the meaning behind it. This study pays attention to the collection of information through interviews and observations as well as the collection of other supporting documents. All information was analyzed using content analysis, especially in interpreting verbal symbols as well as how symbolic interactionism works. This study concludes that the typology of religiosity in Trowulan is patterned into three types, namely: conservative - involutive - orientative in Temon village, progressive - critical - projective type in Sentonorejo village, and innovative - inventive - active type in Trowulan village. The religiosity symbols picked are traditionalists in Temon village with accumulative meanings, modernists in Sentonorejo village with synthetic meanings, and eclectic symbols in Trowulan village with assimilative meanings.
\end{abstract}

Keywords: Community Religiosity

\section{INTRODUCTION}

The biggest challenge in religious life today is how a religious person can define himself in the midst of other religions. At a personal level, the relationship between religious leaders in Indonesia is seen in an increasingly intimate atmosphere, but at the theological level, which is the basis of religion, there is confusion, especially regarding how we should define ourselves in the midst of other religions.

The Majapahit Kingdom was the last major Hindu kingdom that ever existed in the archipelago. The social system of the Majapahit kingdom was, of course, based on the principles of the Hindu religion adopted by most of the people at that time. The entry of Islam through the penetration of pacifique (peace) does not cause social conflict, so that people in this area live their religious lives tolerantly. Islam which was brought into the archipelago in the era of Majapahit rule is a witness to history and its traces can be seen to this day. The peaceful entry of Islam is what causes the people of Majapahit to be free to live their religious life.

The social traces of the Majapahit kingdom that can be seen in the life of the people of Trowulan still reflect what happened in the past. The slogan Bhineka Tunggal Ika, which became the basis for diversity, including in the region, gave an indication that at that time diversity was built on the basis of respecting differences and not making a fuss about them. The area of the Trowulan sub-district is about $11 \times 9 \mathrm{sq} \mathrm{km}$, which looks wider when compared to the area of the Sriwijaya kingdom, which is around 40 sq. $\mathrm{km}$. At that time, the king's city which was the center of Majapahit's power was divided into several Bhre or states. Gajah Mada as patih expanded Majapahit's influence not through conquest but through a diplomatic mechanism where inter-religious meetings were held regularly once every 3 months.

At present, the religious life (Religiosity) of the Trowulan community can actually be seen from the end of the Majapahit Kingdom until the entry of Islam in this region. Trowulan is a witness to history as the locus of the scattered traces of Majapahit's power. Trowulan itself is a sub-district level area that can be found in the western part of the city of Mojokerto bordering the Jombang district. In contrast to the Jombang community, which is thick with Islamic nuances side by side with the life of the abangan community, the Trowulan community has distinctive and unique characteristics. Some of the Trowulan people still hold traditions that existed in the era of Majapahit rule, which can be seen in the many statue craftsmen along the road between the cities of Mojokerto and Jombang. But on the other side, Some of the Trowulan people also have a strong Islamic tradition as the people around the Tikus temple or around the Troloyo cemetery. The two religious models are essentially divided into two poles, namely the Hindu cultured society and the Islamic cultured society. However, that does not mean that it is impossible to develop 
other models besides the two cultures and ways of religion (Religiosity), because initial observations in the field provide unique information, that some members of the Trowulan community consciously live two cultures at once in their diversity, namely Hindu culture as well as Islam. This reality is now strengthening assimilation or at least acculturation in the Trowulan community. The two religious models are essentially divided into two poles, namely the Hindu cultured society and the Islamic cultured society. However, that does not mean that it is impossible to develop other models besides the two cultures and ways of religion (Religiosity), because initial observations in the field provide unique information, that some members of the Trowulan community consciously live two cultures at once in their diversity, namely Hindu culture as well as Islam. This reality is now strengthening assimilation or at least acculturation in the Trowulan community. The two religious models are essentially divided into two poles, namely the Hindu cultured society and the Islamic cultured society. However, that does not mean that it is impossible to develop other models besides the two cultures and ways of religion (Religiosity), because initial observations in the field provide unique information, that some members of the Trowulan community consciously live two cultures at once in their diversity, namely Hindu culture as well as Islam. This reality is now strengthening assimilation or at least acculturation in the Trowulan community. because initial observations in the field provide unique information, that some members of the Trowulan community consciously live two cultures at once in their diversity, namely Hindu culture as well as Islam. This reality is now strengthening assimilation or at least acculturation in the Trowulan community. because initial observations in the field provide unique information, that some members of the Trowulan community consciously live two cultures at once in their diversity, namely Hindu culture as well as Islam. This reality is now strengthening assimilation or at least acculturation in the Trowulan community.

Therefore, it can be asserted assumingly, that the Trowulan community today shows a completely different reality from the purity of Islam or Hinduism. There are some Trowulan people who still live a religious life (Religiosity) according to Hinduism and some others live a religious life (Religiosity) in Islam. And besides that, there are also those who carry out these two elements of the religious system, both Hindu and Muslim in their religious life in an acculturative (coupled with tolerance) and even assimilated (melting into a new system of diversity), such as the existence of a tolerant understanding, namely they both consider properly live a religious life (Religiosity) Hindu and or Islam. This unique fact, with various variations of religious life (Religiosity),

Social symbols always appear in every particular community life. In the era of the Majapahit kingdom, the religious symbols that can be seen are the still standing of the temple as a relic of the Hindu tradition, the discovery of a stupa as a relic of the Buddhist tradition, as well as breaking or at least an Islamic religious life as a relic of Islamic tradition. However, there are symbols that allow researchers to identify how the symbols appear and the meaning behind them. The symbols that appear in the Trowulan community today which are quite meaningful can be seen in the 'Meru' form of the temple as a reflection of Hindu tradition, the 'stupa' form of the Buddhist tradition, and the 'Dome' of the mosque as a reflection of Islamic tradition.

Traceable symbols may take the form of artifacts, but some traditional attitudes and behaviors are the symbols that are most easily seen today. Symbols in the form of behavior such as in the incident of three young people riding motorbikes on Friday, then one young person got off at the mosque to perform Friday prayers, another stopped behind the mosque to drink wine and another played gambling with his friends. A symbol of behavior that implies a necessity for local people to live side by side even though they carry out different rituals.

Another symbol that can be found is the utterance or sentence that comes out in social relations. Speeches or words in the local community are also seen from village ruwatan events such as what happened in Jatisource village. Local religious leaders gathered together to offer congratulations. Ustadz say 'prayer' in Arabic and Javanese. Local faith leaders who are often called kejawen offer prayers through 'silence'. Meanwhile, the Hindu leaders perform the prayer procedure by reading 'gayatri', and it is the turn of the Buddhist leaders to do what is called the 'mantra' reading. The difference in tradition that is symbolically shown in the terminology and procedures of this Ruwatan must have its own meaning and the exploration of meaning like that will be studied in this study.

The reality of religious life (Religiosity) of the Trowulan community that will be studied can certainly be viewed from the information in the field as well as from the symbols that appear in their social reality, both symbols in the form of expressions, words or sentences, or ancient objects which of course have meaning and significance. certain. These are the things that will be explored in this dissertation research proposal.

This research borrows the theory of culture (Koentjoroningrat, Edward Burnett Tylor, Bronislaw Malinowski and JJ Hoenigman), which most of these theorists view that culture or everything that becomes understanding and behavior, customs, and all aspects of human life always shows plural and dynamic elements. in certain societies and can be static in other societies. The theory of symbolic interactionism (which was pioneered by those pioneered by Blumer, 1969; Manis and Meltzer, 1978; Rose, 1962; Snow, 2001) becomes a theory to explain the phenomenon of religious life (Religiosity) with all symbols in every understanding, practice and expectation that surrounds it. community in local research. Religious theories (religious) are also used 
as a theoretical tool in viewing the phenomenon of religiosity in the research area. The social definition paradigm cannot be avoided considering that this research study focuses on the mesosocial scope and the Weberian explanation is the main choice.

\section{METHODOLOGY}

This study uses qualitative research and an ethnographic approach, where the object of research directed at religious life (religiosity) in a society must be approached by tracing the ethnicity and domain of belief in certain community entities. Informants who were recruited were traditional leaders and local communities, religious leaders and community members. Informants were divided into three areas, namely the Temon village community, the Sentonorejo village community and the Trowulan village community located in the Trowulan sub-district. The Trowulan community is thought to have occupied the area of the former center of the Majapahit kingdom, which left many cultural sites with a religious aroma. All data and information obtained through interviews, observations and documentation were then analyzed using content analysis. Why content analysis was chosen by researchers, because the researcher tries to capture verbal symbols in the form of expressions or utterances commonly spoken by the people of Trowulan, to then look for their symbolic meanings. Symbolic interactionism as a theoretical approach is used in addition to capturing the phenomenon of social interaction, it is also used to capture what is the meaning behind every social interaction that occurs.

\section{DISCUSSION}

The movement of one culture to another can be in the form of penetration or breaking through one culture into a particular culture. The penetration of the pacifique is the peaceful penetration of one culture into another. The entry of Islam into the archipelago in its history did not give birth to conflict. Islam was brought by traders and preachers who were concerned by embracing and exploring the character of the people in question. Islam also developed in the tlatah of Majapahit and now its development can be seen. There is a model of society by accepting Islam but it is enough to be friends together. Islam only completes the religious life of a society. Some later Islam became the only one that dominated the religiosity of the people. And, there is a position that Islam is slightly more dominant than other elements. This kind of typology can be seen in this research on the religiosity of the Trowulan community. As the findings in the field, the people of Temon village tend to be fundamentalists in maintaining Javanese traditions. Meanwhile, the people of Sentonorejo village are more open and have created something new in the form of an Islamist society. While the people of Trowulan village still hold Javanese customs but are more dominant in their Islamic traditions.

In the following, the findings and prepositions as a result of the study are presented.

Table1 1. Findings and Prepositions

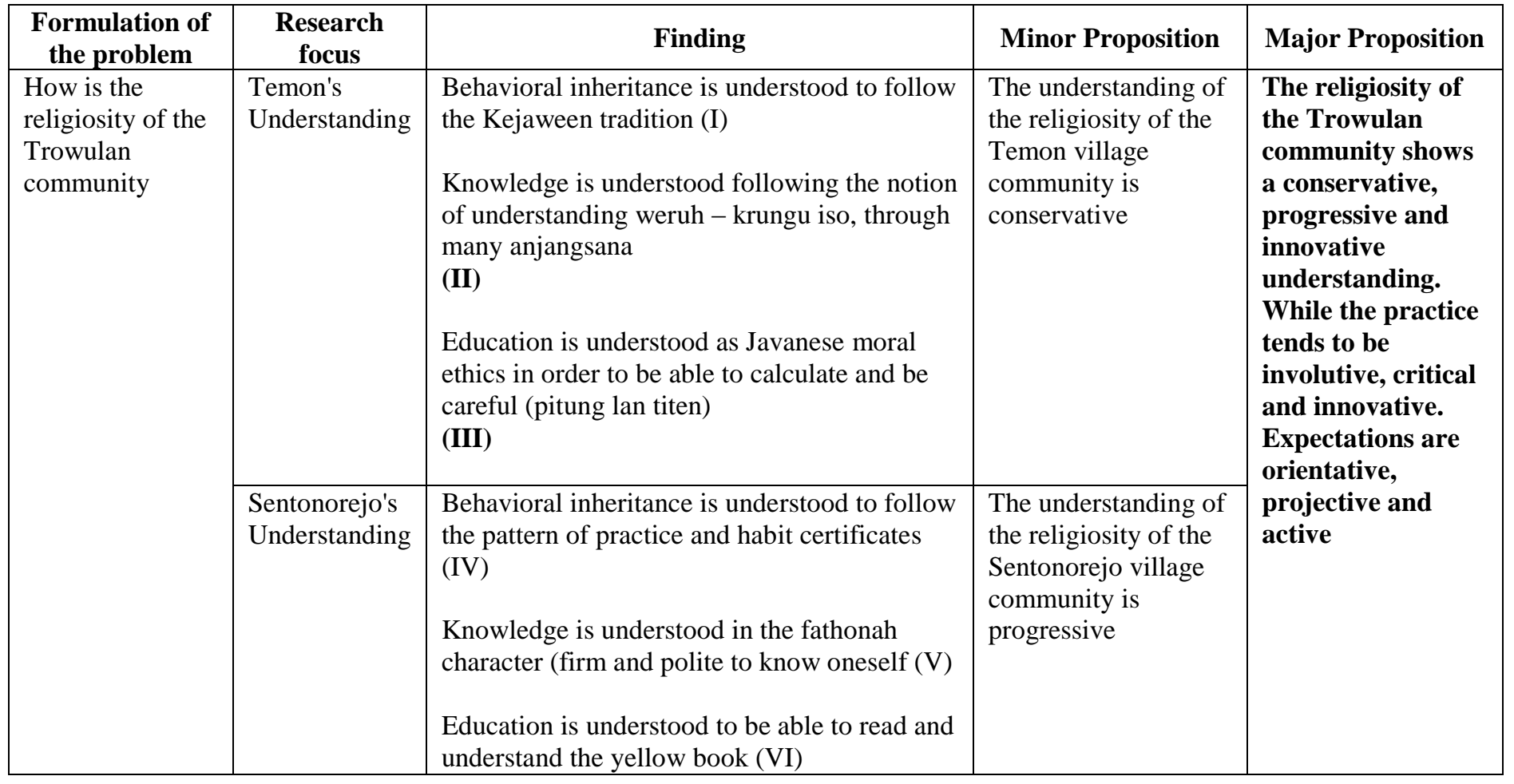


International Journal of Research in Social Science and Humanities (IJRSS), Vol. 2 (6), August- 2020

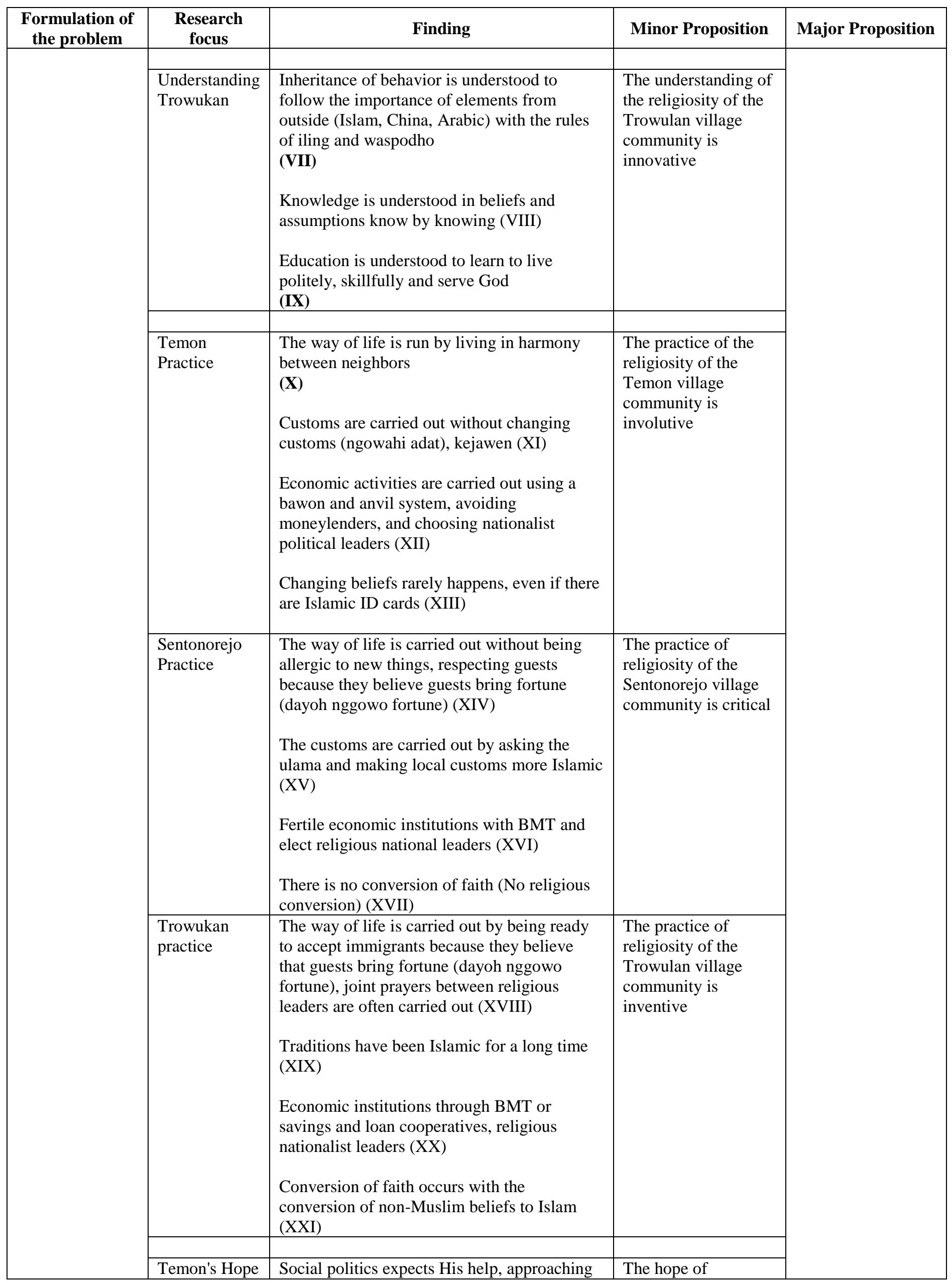


International Journal of Research in Social Science and Humanities (IJRSS), Vol. 2 (6), August- 2020

\begin{tabular}{|c|c|c|c|c|}
\hline $\begin{array}{c}\text { Formulation of } \\
\text { the problem }\end{array}$ & $\begin{array}{l}\text { Research } \\
\text { focus }\end{array}$ & Finding & Minor Proposition & Major Proposition \\
\hline & & $\begin{array}{l}\text { the temple building feels comfortable, } \\
\text { believes in capitalism, and the Jowo Islam } \\
\text { phenomenon (XXII) } \\
\text { Legal and moral benefits with the spirit of } \\
\text { njawani are expected to be useful (XXIII) }\end{array}$ & $\begin{array}{l}\text { religiosity of the } \\
\text { Temon village } \\
\text { community is } \\
\text { orientative }\end{array}$ & \\
\hline & $\begin{array}{l}\text { Sentonorejo's } \\
\text { Hope }\end{array}$ & $\begin{array}{l}\text { Community politics is expected in the } \\
\text { pesantren tradition, by strengthening ngislam } \\
\text { ngiman and ngiksan, rojak hopes to face Allah } \\
\text { with tawhid (XXIV) } \\
\text { Law and morals are expected to be useful } \\
\text { through bahsul masail, as well as self- } \\
\text { awareness and mutual awareness in } \\
\text { maintaining law and morals (XXV) }\end{array}$ & $\begin{array}{l}\text { The religiosity } \\
\text { expectation of the } \\
\text { Sentonorejo village } \\
\text { community is } \\
\text { projective }\end{array}$ & \\
\hline & $\begin{array}{l}\text { Trowukan } \\
\text { Hope }\end{array}$ & $\begin{array}{l}\text { Social politics is expected to be useful by } \\
\text { cultivating Javanese Islamic culture } \\
\text { (maataraman (XXVI) } \\
\text { Law and morals are expected through the role } \\
\text { of the unity of religious leaders (XXVII) }\end{array}$ & $\begin{array}{l}\text { The hope of } \\
\text { religiosity of the } \\
\text { Trowulan village } \\
\text { community is active }\end{array}$ & \\
\hline \multirow[t]{3}{*}{$\begin{array}{l}\text { What is the } \\
\text { symbol of the } \\
\text { Trowulan } \\
\text { Community's } \\
\text { Religiosity and } \\
\text { what is the } \\
\text { meaning behind } \\
\text { it? }\end{array}$} & $\begin{array}{l}\text { Verbal } \\
\text { Symbol of } \\
\text { Temon's } \\
\text { Religiosity }\end{array}$ & $\begin{array}{l}\text { Sites of Bajangratu Temple (power) and Tikus } \\
\text { Temple (Petirtaan) } \\
\text { Paris model house, majapahitan house, red } \\
\text { terracotta bricks, old joglo house, kromo } \\
\text { inggil, kromo madyo, ngoko. } \\
\text { Farm laborers work tools, household tools in } \\
\text { general, sculptural tools. } \\
\text { Verbal symbols in the form of Javanese } \\
\text { utterances such as the proverb 44okum } 44 \text { urip } \\
\text { sak dermo may stop by ngombe, wong tuamu } \\
\text { pengan katon, with the meaning as a reminder } \\
\text { and a guide for living to be good and right, the } \\
\text { meaning of beauty for the sculptor. } \\
\text { (XXVIII) }\end{array}$ & $\begin{array}{l}\text { The symbol of } \\
\text { religiosity of the } \\
\text { Temon village } \\
\text { community tends to } \\
\text { be traditionalist }\end{array}$ & \multirow[t]{3}{*}{$\begin{array}{l}\text { The symbol of the } \\
\text { religiosity of the } \\
\text { Trowulan } \\
\text { community shows } \\
\text { traditionalist, } \\
\text { modernist and } \\
\text { eclectic variants. } \\
\text { The meanings } \\
\text { contained in it are } \\
\text { acculturative, } \\
\text { synthetic and } \\
\text { assimilation }\end{array}$} \\
\hline & $\begin{array}{l}\text { Sentonorejo's } \\
\text { Verbal } \\
\text { Symbol of } \\
\text { Religiosity }\end{array}$ & $\begin{array}{l}\text { The Sentonorejo site is a building strewn with } \\
\text { bricks. According to historical records, this } \\
\text { site is a relic of offerings from the Majapahit } \\
\text { era } \\
\text { There is also the Troloyo Burial Site which } \\
\text { was discovered in the last twenty years. This } \\
\text { site is a relic of the era after the Majapahit } \\
\text { kingdom } \\
\text { And the Kedaton Site, which until now has } \\
\text { been visited by many government or military } \\
\text { officials who want to move up a position or } \\
\text { rank. They are mostly directed at wells or } \\
\text { upas which are said to be beneficial for the } \\
\text { blessing of promotion (XXIX) }\end{array}$ & $\begin{array}{l}\text { The symbol of } \\
\text { religiosity of the } \\
\text { people of } \\
\text { Sentonorejo village } \\
\text { tends to be modernist }\end{array}$ & \\
\hline & $\begin{array}{l}\text { Verbal } \\
\text { Symbol of } \\
\text { Trowulan } \\
\text { Religiosity }\end{array}$ & $\begin{array}{l}\text { Segaran Pond Site (Wealth) and Great } \\
\text { Pendopo Site (Splendence) } \\
\text { Paris model house, majapahitan house, red } \\
\text { terracotta bricks, joglo ancient house, ngoko } \\
\text { The mace of living equipment is as great as a }\end{array}$ & $\begin{array}{l}\text { The symbol of } \\
\text { religiosity of the } \\
\text { Trowulan village } \\
\text { community tends to } \\
\text { be eclectic }\end{array}$ & \\
\hline
\end{tabular}


International Journal of Research in Social Science and Humanities (IJRSS), Vol. 2 (6), August- 2020

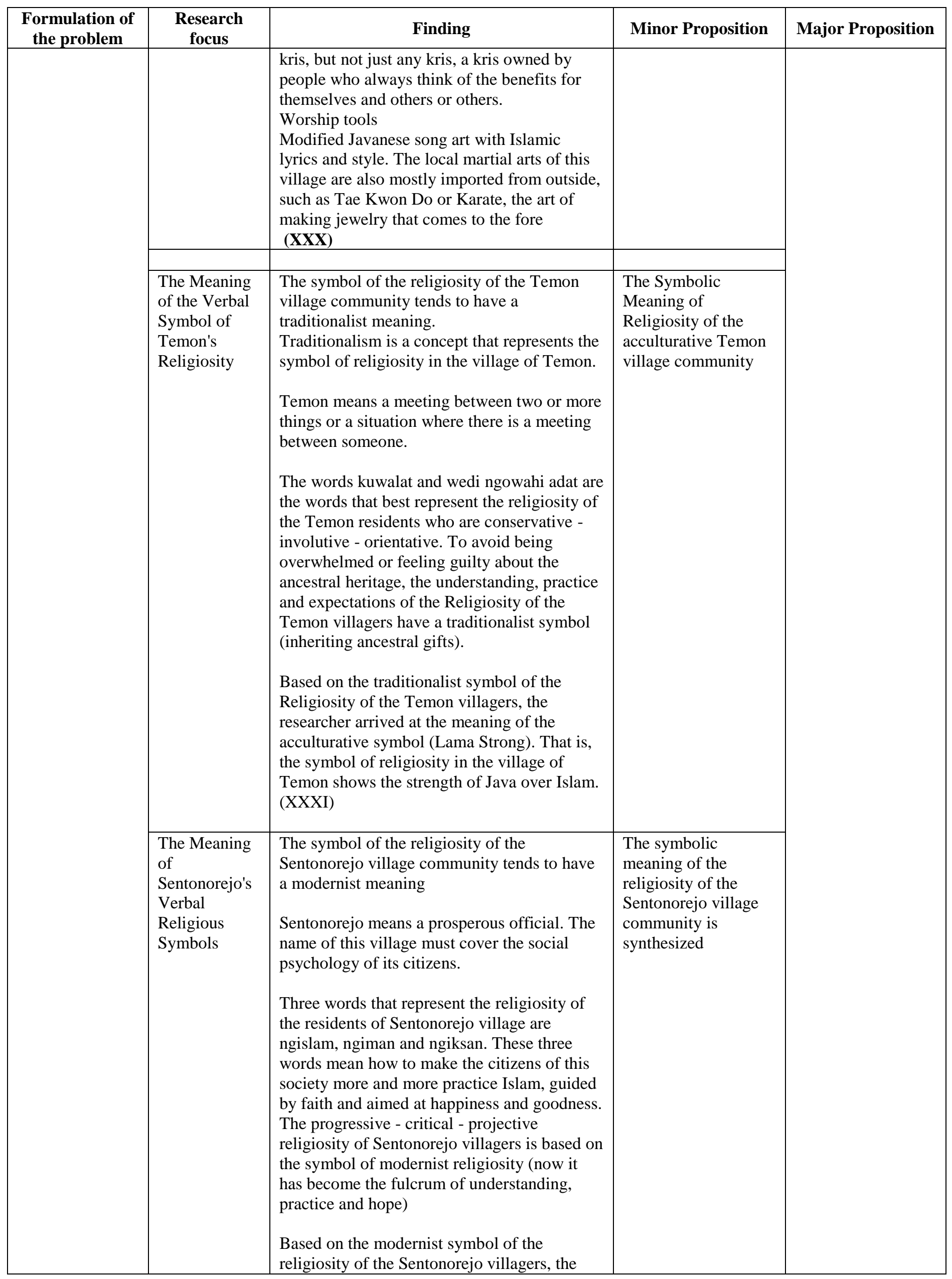


International Journal of Research in Social Science and Humanities (IJRSS), Vol. 2 (6), August- 2020

\begin{tabular}{|c|c|c|c|c|}
\hline $\begin{array}{c}\text { Formulation of } \\
\text { the problem }\end{array}$ & $\begin{array}{l}\text { Research } \\
\text { focus }\end{array}$ & Finding & Minor Proposition & Major Proposition \\
\hline & & $\begin{array}{l}\text { researcher arrived at the meaning of the } \\
\text { Synthesis (Baru Beda) symbol. That is, the } \\
\text { symbol of religiosity in the village of } \\
\text { Sentonorejo shows something new and } \\
\text { completely different from before (XXXII). }\end{array}$ & & \\
\hline
\end{tabular}

Source: Processed from information collected from informants and prepositioned

Furthermore, symbolic interactionism is a way of capturing symbols that appear in conditions between the actions of each interacting individual. The most commonly captured symbols are words or sentences that express the contents of the communicator's intent to the communicant. Every word that comes out between the communicator and the communicant is what continuously produces a social interaction. Interactive social interaction is characterized by the smooth process of direct contact and communication. Every communicator acts by speaking, so at the same time the communicant reacts after receiving the message behind the words. And so on, then there is an intense interaction between the communicator and the communicant. In contrast to Weberian, Blumerian actually puts words as the focus, because behind the words there is a symbolic meaning. If Weber is more on verstehen or its interpretation as the main reference, then Blumer provides a new view that complements Weber's idea of interaction on the need to capture symbols behind words. If you want to be fair, actually what Weber and Blumer say is the same. The symbol of the words that we are trying to find the meaning is a Weber-style process of interpretation. This research actually uses the workings of symbolic interactionism. Excavation of data and information based on two research questions related to the religiosity of the Trowulan community and the symbolic meaning behind the symbol of the Trowulan community's religiosity showed the findings and the results were that So Blumer provides a new view that complements Weber's idea of interaction in the need to capture the symbols behind words. If you want to be fair, actually what Weber and Blumer say is the same. The symbol of the words that we are trying to find the meaning is a Weber-style process of interpretation. This research actually uses the workings of symbolic interactionism. Excavation of data and information based on two research questions related to the religiosity of the Trowulan community and the symbolic meaning behind the symbol of the Trowulan community's 
religiosity showed the findings and the results were that So Blumer provides a new view that complements Weber's idea of interaction in the need to capture the symbols behind words. If you want to be fair, actually what Weber and Blumer say is the same. The symbol of the words that we are trying to find the meaning is a Weber-style process of interpretation. This research actually uses the workings of symbolic interactionism. Excavation of data and information based on two research questions related to the religiosity of the Trowulan community and the symbolic meaning behind the symbol of the Trowulan community's religiosity showed the findings and the results were that The symbol of the words that we are trying to find the meaning is a Weber-style process of interpretation. This research actually uses the workings of symbolic interactionism. Excavation of data and information based on two research questions related to the religiosity of the Trowulan community and the symbolic meaning behind the symbol of the Trowulan community's religiosity showed the findings and the results were that The symbol of the words that we are trying to find the meaning is a Weber-style process of interpretation. This research actually uses the workings of symbolic interactionism. Excavation of data and information based on two research questions related to the religiosity of the Trowulan community and the symbolic meaning behind the symbol of the Trowulan community's religiosity showed the findings and the results were that

a. If the understanding of the religiosity of a conservative society is accompanied by involutive practice and aimed at orientative desires, then the symbol of religiosity that can be picked is traditionalist and has acculturative meaning.

b. If the understanding of the religiosity of a progressive society is accompanied by critical practice and is aimed at projective desires, then the symbol of religiosity that can be picked is modernist and has a synthetic meaning.

c. If the understanding of orientative community religiosity is accompanied by inventive practice and is aimed at active desires, then the symbol of religiosity that can be picked is eclectic and has assimilative meaning.

The findings and propositions presented along with content analysis as a discussion technique confirm the power of explaining the various theories used in the framework of thought. Koetjoroningrat's cultural theory and various cultural theorists have found its confirmation in the empirical realm. The theory of symbolic interactionism, which puts forward words as the main symbol in an interaction, has also been well confirmed after a long time of digging for information in the field. Dewey's sociological theory of religion, which pioneered the existence of powerful forces outside of human beings, is increasingly confirmed by the findings of understanding, practice and expectations of Religiosity. In the field. Theories and conceptions of religion that are typified in so many ways are also well confirmed one by one after the researchers plunged into digging for information in the field. The Weberian-style social definition paradigm that is verstehen also contributes to researchers in limiting which social scope can be used as the scope of research. The scope of the three villages as representatives of the Trowulan community at least helps researchers find the religious characteristics of the Trowulan community. The most confirmative theoretical implication is the theoretical explanation that accompanies the important findings as the novelty of this study.

The following is a tabulation of the entire research in the form of a table that makes it easier for researchers to identify and explain the results of this study.

Table 2. Trowulan Community Religiosity

\begin{tabular}{|l|l|l|l|}
\hline & \multicolumn{1}{|c|}{ Temon } & \multicolumn{1}{c|}{ Sentonorejo } & \multicolumn{1}{c|}{ Trowulan } \\
\hline Understanding & Conservative & Progressive & Innovative \\
\hline Practice & Involutive & Critical & inventive \\
\hline Hope & Orientative & Projective & Active \\
\hline & & & \\
\hline Symbol & Traditionalist & modernist & Eclectic \\
\hline Symbolic Meaning & Acculturative (Long Strong) & Synthesis (Just Different) & Assimilation (New Strong) \\
\hline
\end{tabular}

Source: Extracted from the whole research

It is clear that this research has reached novelty, The new finding is that the religiosity of the Trowulan community as a place for several historical sites has experienced the preservation of Javanese traditions with traditionalist symbols and accumulative meanings (Temon Village), gave birth to new traditions with modernist symbols meaning synthesis (Sentonorejo village) and tolerated old traditions with new traditions with eclectic symbols meaning assimilative (Trowulan village). The description in the table above makes it easier for researchers to explain the novelty of the phenomenon and reality of the distinctive and unique religiosity of the Trowulan community. 


\section{CONCLUSION}

The final part of the scientific work report must present the formulation of conclusions. The conclusion is a conclusive description of the researcher in answering the research questions and their focus. This study departs from two questions, namely how religious life (Religiosity) is viewed from the perspective of symbolic interactionism in the Trowulan community and what are the meanings contained in the symbols that appear in religious life (Religiosity) viewed from the perspective of symbolic interactionism in the Trowulan community?. These two research questions convey the researcher's findings and the formulation of theoretical implicative sentences as described in the discussion points. Based on all that, the conclusions that researchers can convey are as follows.

1. The religiosity of the Trowulan community is distinguished in three areas and is divided into several indicators, namely understanding, experience and hope. In each research area, there are differences in the typology of religiosity. The typology of the religiosity of the Trowulan community in Temon village is patterned to be conservative - involutive - orientative, meaning that their understanding of religiosity is more concerned with maintaining the inheritance of understanding in line with the concept of "ojo ngowahi adat", the practice is carried out in an involutive manner, namely carrying out what has been traditionally carried out, mainly the kejawe tradition, and the hope is focused on the orientative thing is to have no hope other than what the ancestors had hoped for. While the religious typology of the Trowulan community in Sentonorejo village is patterned progressively - critically - projectively, it means that his religious understanding really wants improvement even though it has to be different from local traditions, his practice is carried out bravely, dares to hit the walls of tradition, for the sake of something better, and his hopes are resolved to better desires and desires. Furthermore, the religious typology of the Trowulan community in Trowulan village is patterned in an innovative - inventive - active manner, meaning that their understanding of religiosity allows for a renewal of understanding, their practice brings out new things and ways, while their hopes are at stake for the integration of several elements above the desire and desire to take new, more hegemonic elements. juxtaposing elements of the old tradition. for something better, and his hopes resolve to better desires and desires. Furthermore, the religious typology of the Trowulan community in Trowulan village is patterned in an innovative - inventive active manner, meaning that their understanding of religiosity allows for a renewal of understanding, their practice brings out new things and ways, while their hopes are at stake for the integration of several elements above the desire and desire to take new, more hegemonic elements. juxtaposing elements of the old tradition. for something better, and his hopes resolve to better desires and desires. Furthermore, the religious typology of the Trowulan community in Trowulan village is patterned in an innovative - inventive - active manner, meaning that their understanding of religiosity allows for a renewal of understanding, their practice brings out new things and ways, while their hopes are at stake for the integration of several elements above the desire and desire to take new, more hegemonic elements. juxtaposing elements of the old tradition.

2. The religious symbols of the Trowulan community are also divided into three typologies. The symbol of religiosity of the Trowulan community in Temon village is a traditionalist symbol and implies an acculturative meaning of religiosity (strengthening the old / Javanese while side by side with Islamic traditions. While the symbol of religiosity of the Trowulan community in Sentonorejo village is a modernist symbol that tends to synthetic meanings, giving rise to something new and new. And, the symbol of the religiosity of the Trowulan community in Trowulan village is eclectic, namely strengthening the combination in which the most relevant elements are strong, in this case the Islamic tradition is stronger than the Kejawen tradition, which in turn gives assimilative symbolic meaning (the new element is more dominant).

\section{REFERENCES}

Abdul Munir Mulkhan, Islam and the Prerequisites of Civil Society Culture, in Kompas, January 25, 1999.

Allen, B., \& Reser, D. (1990). Content analysis in library and information science research. Library \& Information Science Research, 12(3), 251-260.

Azra, Azyumardi, 2003, Giving to All: Discourse and Practice of Islamic Philanthropy, Jakarta: IAIN Syarif Hidayatullah-Teraju.

Bellah, Robert N., 1992, Tokugawa Religion: The Roots of Japanese Culture, Jakarta: Gramedia.

Berger, Peter L and Thomas Luckman, 1991, Langit Suci: Religion as a Social Reality, Jakarta: LP3ES.

Beyer, Peter in Richard H. Roberts (ed.), 1995, Religion and The Transformations of Capitalism, cet. I, London: Routledge.

Cliffort Geertz, Abangan, Santri, Priyayi in Javanese Society, Jakarta, Pustaka Jaya, 1989

De Wever, B., Schellens, T., Valcke, M., \& Van Keer, H. (2006). Content analysis schemes to analyze transcripts of online asynchronous discussion groups: A review. Computers \& Education, 46, 6-28.

Doyle Paul Johnson, Classical and Modern Sociological Theories, Jakarta, Gramedia, 1994 
Dwaine Marvick, Elites, University of California, in Encyclopedia of Social Sciences.

Hsieh, H.-F., \& Shannon, S.E. (2005). Three approaches to qualitative content analysis. Qualitative Health Research, 15(9), 12771288.

Klaus Krippendorff, Content Analysis An Introduction to Its Methodology

Klaus Krippendorff, Content Analysis: An Introductions to its Methodology (Second Edition), California: Sage Publication, 2004.

Klaus Krippendorff, Content Analysis: Introduction to Theory and Methodology, Farid Wajdi translation, Jakarta, Rajawali Press, 1991.

Koentjaraningrat, 1997, Culture, Mentality and Development, Jakarta: Gramedia.

Kusnadi, Horseshoe Society, Cultural Construction \& Political Violence, in Journal of Humanities Vol. II No. 2.July 2001

Mayring, P. (2000). Qualitative content analysis. Forum: Qualitative Social Research, 1(2). Retrieved July 28, 2008, from http://217.160.35.246/fqs-texte/2-00/2-00mayring-e.pdf.

Muhammad Sobary, People's Culture, Political \& Religious Dimensions, Jogjakarta, Bentang, 1996

Pals, Daniel L., 2001, Seven Theories of Religion: from E. B. Tylor's Animism, Karl Marx's Materialism to Cliffort Geertz's Cultural Anthropology, Yogyakarta: Qalam.

Patton, M.Q. (2002). Qualitative Research and Evaluation Methods. Thousand Oaks, CA: Sage.

Quthub, Muhammad, 1993, Answers to the Wrong World of Western Thought on AI-Islam, in ter. Alwi A. S., Bandung: CV. Diponegoro.

Robert Philip Weber, Basic Content Analysis, California: Sage Publications, 1990.

Robertson, Roland, 1995, Religion in Sociological Analysis and Interpretation, Jakarta: Raja Grafindo Persada.

Ron Hatley, Mapping Cultural Regions of Java, Monash University, 1984

Schilling, J. (2006). On the pragmatics of qualitative assessment: Designing the process for content analysis. European Journal of Psychological Assessment, 22(1), 28-37.

Sobary, Muhammad, 2007, Islamic Ethics: From Individual Piety to Social Piety, Yogyakarta: LKIS.

Walter L. Adamson, Hegemony and Revolution: Al-Bukhari Study of Antonio Gramsci'syariat Islam Political and Cultural Theory, Berkeley, CA, University of California Press

Weber, Max, 2000, Protestant Ethics and the Spirit of Capitalism, Surabaya: Promothea.

Weber, Max, 2006, Comprehensive Study of the Sociology of Culture, Yogyakarta: IRCiSoD 